Lepr Rev (1991) 62, 255-261

\title{
Evaluation of gelatin particle agglutination assay for the detection of anti-PGLI antibodies. Comparison with ELISA method and applicability on a large scale study using blood collected on filter paper
}

\author{
SUZANNE CHANTEAU, J-L CARTEL, J P BOUTIN \& \\ J ROUX \\ Institut Territorial de Recherches Medicales, Louis Malarde, B P 30 , \\ Papeete, Tahiti, French Polynesia
}

Accepted for publication 1 February 1991

\begin{abstract}
Summary Given the technical difficulties of the ELISA method, a gelatin particle agglutination test (MLPA) has been developed recently for the detection of anti-PGLI antibodies. The purpose of this study was to compare these 2 tests. MLPA was found to be less specific than ELISA ( $91 \%$ versus $98 \%, \chi^{2}=66 \cdot 8$, $p<0.001)$. The sensitivity of both tests was of $95 \%$ for the diagnosis of multibacillary patients. In the case of paucibacillary patients. MLPA was found to be less sensitive than ELISA $\left(21 \%\right.$ versus $\left.35 \%, \chi^{2}=6.98, p>0.01\right)$. The agreement between the 2 tests for a positive or a negative result was satisfying $(85 \%$ to $100 \%)$, except for the weakly seropositive individuals $(71 \%)$. The correlation between OD obtained with ELISA and antibody titre obtained with MLPA was statistically significant $(r=0.70, p<0.001)$. Conversely to ELISA, MLPA was not applicable on blood samples absorbed on filter paper without a serious loss of sensitivity. In conclusion, this study demonstrated that the MLPA test can only reliably detect anti-PGLI antibodies in multibacillary cases.
\end{abstract}

\section{Introduction}

A specific phenolic glycolipid, the PGLI, has been isolated from Mycobacterium leprae and it was demonstrated that most of the multibacillary leprosy patients displayed high titres of IgM anti-PGLI. ${ }^{2}$ Numerous studies have been undertaken to evaluate the usefulness of this serology for the diagnosis or the prognosis of leprosy, ${ }^{3-6}$ and for seroepidemiological studies. ${ }^{7,8}$ Indirect ELISA was the method classically used. Given the technical difficulties for untrained personnel to apply this method, a gelatin particle agglutination test (MLPA) on microtiter plates has been developed recently. ${ }^{9}$ The agglutination test as compared to ELISA assay, is usually rapid and simple to perform. The aims of this work are first to compare and study the correlations between ELISA and 
MLPA tests for the diagnosis of leprosy, and secondly to define the applicability of the MLPA test on blood samples collected on filter paper.

\section{Methodology}

SERA TESTED

Negative controls

They were composed of 414 healthy Polynesian individuals without known contact with leprosy patients and 32 healthy persons from a nonendemic country.

\section{Leprosy patients}

We have tested the sera from 44 leprosy patients before treatment. According to the Ridley-Jopling scale they were classified as 21 multibacillary patients (4 BL, $17 \mathrm{LL}$ ) and 23 paucibacillary patients (7 I, 6 BT, 8 TT, $2 \mathrm{~N}$ ).

\section{Household contacts}

A total of 262 household contacts were selected for this study. Using the ELISA method, 109 of them were seronegative and 153 were seropositive. These latter subjects were classified in 3 groups according to their antibody level: OD492 $\mathrm{nm}[0 \cdot 200-0 \cdot 300]$ for 66 , [0.300-0.600] for 66 and [ $>0 \cdot 600]$ for 21 of them.

The sequential sera from 6 contact's subjects who further developed leprosy (4 I, 1 BT, 1 LL) were also tested.

\section{ANTI-PGLI ELISA TEST}

The conventional indirect ELISA method for the detection of human IgM antibodies has been described in a previous study. ${ }^{10}$ The antigen used was the chemically synthesized trisaccharide NTP conjugated to bovine serum albumin kindly supplied by $\mathrm{Dr} T$ Fujiwara. ${ }^{11}$ The sera were screened at $1 / 250$ dilution and the positives were semiquantitated by two-fold dilutions. The threshold of ELISA test was $0 \cdot 200$ OD according to previous studies on Polynesian sera. ${ }^{12}$

\section{PARTICLE AGGLUTINATION TEST MLPA}

The MLPA kits in which the gelatin particles were sensitized with NTP antigen (Fujirebio Inc, Japan) were kindly supplied by the WHO Regional Office for the Western Pacific. The protocol of the test was according to the manufacturer's specification. A negative control was achieved with unsensitized gelatin particles at 1/16 final dilution of each serum. All the sera were screened with sensitized particles at $1 / 32$ final dilution and a semiquantitative test using two-fold dilutions was conducted for the positive sera. The antibody titre was expressed as the highest dilution giving a positive pattern. The interpretation of the agglutination pattern was according to the manufacturer's criteria: negative (no agglutination or inconclusive agglutination), positive (complete agglutina- 
tion). Because of the subjective analysis on the degree of agglutination, the sera were coded.

\section{MLPA on blood collected on filter paper}

Blood obtained by pricking the finger-tip was absorbed on Whatman No. 1 paper cards with $5 \mathrm{~mm}$ diameter precut discs (Serobuvard, Laboratoire LDA, France). ${ }^{13}$ The processing of these samples was as followed: four paper discs per patient were eluted overnight into 100 microlitres of MLPA diluent, which is the minimum volume required to immerse the discs. According to the volume of blood absorbed on the filter, the final dilution of the sera for MLPA test was $1 / 25$ for the control with unsensitized particles and $1 / 50$ for the screening with sensitized particles.

\section{STATISTICAL ANALYSIS}

The agreement rate between MLPA and ELISA in detecting positive and negative subjects was calculated as follows: number of positive results + number of negative results by the 2 methods/total number sera tested $\times 100$. The correlation between ELISA and MLPA was calculated according to the least square method and the $\chi^{2}$ method was used to compare percentages.

\section{Results}

\section{SPECIFICITY FOR SERODIAGNOSIS OF LEPROSY}

All of the 32 sera from healthy subjects living in nonendemic countries were negative both in ELISA and MLPA ( $100 \%$ of the agreement rate). The results of the 414 healthy Polynesian subjects are reported in Table 1 and the agreement rate for this group was $86 \%$.

The specificity of MLPA and ELISA was $91.5 \%$ and $98 \%$, respectively, when considering healthy Polynesian as negative controls $\left(\chi^{2}=66 \cdot 8, p<0 \cdot 001\right)$.

Table 1. Comparison between MLPA and ELISA tests for detecting anti-PGLI antibodies in negative controls and patients

\begin{tabular}{|c|c|c|c|c|c|c|}
\hline \multirow[b]{2}{*}{ Group } & \multirow{2}{*}{$\begin{array}{l}\text { No. of serum } \\
\text { specimens }\end{array}$} & \multicolumn{4}{|c|}{ No. of specimens with test result } & \multirow{2}{*}{$\begin{array}{l}\% \\
\text { Agreement } \\
\text { rate }\end{array}$} \\
\hline & & $\mathrm{E}^{+} \mathrm{M}^{+}$ & $\mathrm{E}^{+} \mathrm{M}^{-}$ & $\mathrm{E}^{-} \mathrm{M}^{+}$ & $\mathrm{E}^{-} \mathrm{M}^{-}$ & \\
\hline Polynesian negative controls & 414 & $8^{*}$ & 1 & $27 \dagger$ & 378 & 86 \\
\hline Multibacillary patients & 21 & $20 \ddagger$ & 0 & 0 & 1 & 100 \\
\hline Paucibacillary patients & 23 & $5 \S$ & 3 & 0 & 15 & 82 \\
\hline
\end{tabular}

E, ELISA; M, MLPA.

$*$ MLPA titre $=32 \times 4$ and $64 \times 4$.

$\dagger$ MLPA titre $=32 \times 15,64 \times 10$ and $128 \times 2$.

$\ddagger$ MLPA titre $=64 \times 1,128 \times 7,256 \times 4,512 \times 3,1024 \times 1,2048 \times 2$ and $8192 \times 2$.

$\S$ MLPA titre $=32 \times 4$ and $64 \times 1$. 


\section{SENSITIVITY FOR SERODIAGNOSIS OF LEPROSY}

The results obtained in using the 2 tests on patients' sera are found in Table 1. For the multibacillary patients the agreement rate was $100 \%$ between the 2 tests and the sensitivity $95 \%$ for both tests. For the paucibacillary patients the agreement rate was $82 \%$ and sensitivity was $21 \%$ for MLPA and $35 \%$ for ELISA $\left(\chi^{2}=6 \cdot 98, p<0 \cdot 01\right)$.

\section{DETECTION OF ANTI-PGLI IN HOUSEHOLD CONTACTS}

A total of 262 selected contacts displaying a large range of antibody level were tested. The agreement rates between the 2 tests according to the different antibody level obtained by ELISA are reported in Table 2. A significant correlation was obtained between the MLPA titres and the optical density obtained in ELISA $(r=0 \cdot 70, p<0 \cdot 001)$.

The sequential sera from 6 contacts who developed leprosy (1 LL, 1 BT, 4 I) could be tested by ELISA and MLPA. The results are reported in Table 3. The agreement rate between MLPA and ELISA was $81 \%$.

\section{APPLICABILITY OF MLPA FOR BLOOD SAMPLES COLLECTED ON FILTER PAPER}

A total of 130 pairs of sera and blood absorbed on filter paper was tested with MLPA. Using the sera, 58 individuals (45\%) were seronegative and $72(55 \%)$ were seropositive. Using whole blood collected on Whatman paper, $109(84 \%)$ were seronegative and 21 $(16 \%)$ were seropositive. These latter individuals represented only $29 \%$ of the subjects found seropositive using the serum.

\section{Discussion}

The objectives of this study were to compare the gelatin particle agglutination test MLPA and the standard indirect ELISA test for the detection of anti-PGLI antibodies, and to evaluate the applicability of MLPA on blood samples collected on filter paper.

For the serodiagnosis of leprosy patients, MLPA was found to be less specific than

Table 2. Agreement between MLPA and ELISA for 262 contacts subjects presenting different anti-PGLI levels as determined by ELISA. Coefficient correlation $r=0 \cdot 70(p<0 \cdot 001)$

\begin{tabular}{|c|c|c|c|c|}
\hline \multirow{2}{*}{$\begin{array}{l}\text { ELISA activity } \\
\mathrm{OD}_{492} \mathrm{~nm}\end{array}$} & \multirow{2}{*}{$\begin{array}{c}\text { Number } \\
\text { sera tested }\end{array}$} & \multicolumn{2}{|c|}{ MLPA } & \multirow{2}{*}{$\begin{array}{c}\text { Agreement rate } \\
(\%)\end{array}$} \\
\hline & & + & - & \\
\hline$<0.200(-)$ & 109 & $16^{*}$ & 93 & 85 \\
\hline$[0 \cdot 200-0 \cdot 300](+)$ & 66 & $47 \dagger$ & 19 & 71 \\
\hline$[0 \cdot 300-0 \cdot 600](+)$ & 66 & $62 \ddagger$ & 4 & 94 \\
\hline$>0.600(+)$ & 21 & $20 \S$ & 1 & 95 \\
\hline
\end{tabular}

* MLPA titre: $32 \times 9,64 \times 4,128 \times 3$.

$\dagger$ MLPA titre: $32 \times 29,64 \times 16,128 \times 2$.

$\ddagger$ MLPA titre: $32 \times 20,64 \times 35,128 \times 7$.

$\S$ MLPA titre: $64 \times 6,128 \times 12,256 \times 2$. 
Table 3. MLPA and ELISA in sequential sera from 6 contacts who developed leprosy

\begin{tabular}{|c|c|c|c|c|}
\hline Subject & $\begin{array}{c}\text { Months before } \\
\text { diagnosis }\end{array}$ & $\begin{array}{l}\text { ELISA } \\
\mathrm{OD}_{492} \mathrm{~nm}\end{array}$ & $\begin{array}{l}\text { MLPA } \\
\text { titre }\end{array}$ & $\begin{array}{c}\text { Type of leprosy } \\
\text { developed }\end{array}$ \\
\hline 1 & $\begin{array}{r}24 \\
0\end{array}$ & $\begin{array}{l}0 \cdot 601(+) \\
1 \cdot 374(+)\end{array}$ & $\begin{array}{lr}(+) & 64 \\
(+) & 256\end{array}$ & LL \\
\hline 2 & $\begin{array}{r}27 \\
13 \\
3 \\
0\end{array}$ & $\begin{array}{l}0.003(-) \\
0 \cdot 215(+) \\
0 \cdot 500(+) \\
0.634(+)\end{array}$ & $\begin{array}{r}(-) \\
(+) 32 \\
(+) 32 \\
(+) 32\end{array}$ & BT \\
\hline 3 & $\begin{array}{r}23 \\
0\end{array}$ & $\begin{array}{l}0 \cdot 180(-) \\
0 \cdot 346(+)\end{array}$ & $\begin{array}{l}(-) \\
(-)\end{array}$ & I \\
\hline 4 & $\begin{array}{l}8 \\
0\end{array}$ & $\begin{array}{l}0 \cdot 348(+) \\
0 \cdot 327(+)\end{array}$ & $\begin{array}{l}(+) 64 \\
(+) 64\end{array}$ & I \\
\hline 5 & $\begin{array}{r}16 \\
10 \\
0\end{array}$ & $\begin{array}{l}0 \cdot 189(-) \\
0 \cdot 188(-) \\
0 \cdot 390(+)\end{array}$ & $\begin{array}{r}(-) \\
(+) 32 \\
(+) 32\end{array}$ & I \\
\hline 6 & $\begin{array}{r}43 \\
16 \\
0\end{array}$ & $\begin{array}{l}0 \cdot 189(-) \\
0 \cdot 147(-) \\
0 \cdot 150(-)\end{array}$ & $\begin{array}{r}(-) \\
(+) 64 \\
(-)\end{array}$ & I \\
\hline
\end{tabular}

ELISA $\left(\chi^{2}=66 \cdot 8, p<0 \cdot 001\right)$. However, it is noteworthy that more than half of the false positives using MLPA (15/27) that were negative in ELISA, had low antibody titre equal to 32 . The positive pattern may be due to some biophysical peculiarities in some sera, that resulted in a non-specific agglutination of the particles. The sensitivity was $95 \%$ for both tests when considering the multibacillary patients but for the paucibacillary patients, ELISA $(35 \%)$ was more sensitive than MLPA $(21 \%)\left(\chi^{2}=6.98, p<0.01\right)$. The paucibacillary patients generally display a very low level of anti-PGLI antibodies that cannot be detected by MLPA. Anyhow, for these latter patients the PGLI is not a suitable antigen for serodiagnosis. The specificity of MLPA can be improved to $96 \%$ if its cut-off is fixed at 64 instead of 32, but in that case the sensitivity for detecting the paucibacillary form of the disease drops to $4 \%$ as it remained at $95 \%$ for the multibacillary form.

The agreement rate for positive or negative results between MLPA and ELISA was as good for patients as for contacts and ranged from $71 \%$ to $100 \%$. In general the concordance was the lowest for the individuals who were weakly positive in ELISA. The correlation between the MLPA titres and OD in ELISA was highly significant $(r=0 \cdot 7$, $p<0.001)$.

Because the agglutination test is rapid and easy to perform, it may constitute an interesting assay for large scale serological studies. Blood collected on filter paper has been used successfully in ELISA for the detection of anti-PGLI antibodies. ${ }^{13}$ In this connection, we compared the results of MLPA obtained with the serum and with blood eluted from filter paper. The agreement rate obtained was fair (61\%) and only $29 \%$ of the positive individuals were found positive using filter paper. Because the titres were much lower when using blood absorbed on filter paper than when using serum obtained by venepuncture, the weakly positive subjects turned out to be negative. This may be explained by an inefficient elution of antibodies from the paper discs. This technical 
problem has proved difficult to overcome as, conversely to ELISA, a high concentration of sera is needed for MLPA and thus the volume of diluent used is too small to ensure a complete antibody elution. However, according to whether the prerogative of the test for a precise use is specificity or sensitivity, one can raise the cut-off, i.e. the screening dilution of the sera, and consequently use a larger volume of diluent for soaking the filter paper discs.

The usefulness of the detection of anti-PGLI has been extensively evaluated for the serodiagnosis of patients, the subclinical diagnosis among contact population, or the monitoring of patients during chemotherapy. The conclusions of these studies were that anti-PGLI assay can be used as an additional tool for the diagnosis of multibacillary patients, and also as an alternate tool to the BI determination for the surveillance of multibacillary patients after treatment. In countries where the implementation of such a test is planned and where the technical facilities are too limited for setting up the ELISA method, the agglutination MLPA test may be a good substitute.

In conclusion, in spite of a lower specificity and sensitivity of MLPA for the detection of paucibacillary patients than ELISA, the agreement and the correlation between the 2 tests were satisfying. This study demonstrated that the MLPA test can only reliably detect the anti-PGLI antibodies in multibacillary patients and conversely to ELISA, MLPA was not applicable on blood absorbed on filter paper without a serious loss of sensitivity.

\section{Acknowledgments}

We are most grateful to the Regional WHO Office of Manila (Philippines) for supplying the MLPA kits and supporting this study. Our thanks are due to C Plichart and P Luquiaud for their technical assistance.

\section{References}

${ }^{1}$ Hunter SW, Fujiwara T, Brennan P. Structure and antigenicity of the major specific glycolipid antigen of Mycobacterium leprae. J Biol Chem, 1982; 257: 15072-8.

2 Cho SN, Yanagihara DL, Hunter SW, Gelber RH, Brennan P. Serological specificity of phenolic glycolipid from Mycobacterium le prae and use in serodiagnosis of leprosy. Infect Immun, 1983; 41: 1077-83.

3 Buchanan TM, Young DB, Miller RA, Khanolkar SR. Serodiagnosis of infection with Mycobacterium leprae. Int J Lepr, 1983; 51: 524-30.

${ }^{4}$ Brett SJ, Payne GN, Gigg P, Burgess P, Gigg R. Use of synthetic glycoconjugates containing the Mycobacterium leprae specific and immunodominant epitope of phenolic glycolipid $\mathrm{I}$ in the serology of leprosy. Clin exp Imm, 1986; 64: 476-83.

5 Douglas JT, Cellona RV, Abalos RM, Madarang MG, Fajardo T. Serological reactivity and early detection of leprosy among contacts of lepromatous patients in Cebu, the Philippines. Int J Lepr, 1987; 55: 718-21.

${ }^{6}$ Chanteau S, Cartel JL, Guidi C, Plichart R, Bach MA. Seroepidemiological study of 727 household contacts of leprosy patients in French Polynesia using disaccharide-octyl-BSA as antigen. Int J Le pr, 1987; 55: 626-32.

7 Baumgart K, Britton W, Basten A, Bagshawe A. Use of phenolic glycolipid I for the serodiagnosis of leprosy in a high prevalence village in Papua New Guinea. Trans Roy Soc Trop Med Hyg, 1987; 81: 1030-2.

${ }^{8}$ Cartel JL, Chanteau S, Boutin JP, Plichart R, Richez P, Roux JF, Grosset JH. Assessment of anti-PGLI IgM levels using ELISA test for detection of $M$. leprae infection in populations of South Pacific Islands. Int J Lepr, 1990; 58: 512-17.

${ }^{9}$ Izumi S, Fujiwara T, Ikeda M, Nishimura Y, Sugiyama K, Kawatsu K. Novel gelatin particle agglutination test for the serodiagnosis of leprosy in the field. J Clin Microbiol, 1990; 28: 525-9.

10 Chanteau S, Cartel JL, Roux J, Plichart R, Bach MA. Comparison of synthetic antigens for detecting antibodies to phenolic glycolipid I in patients with leprosy and their household contacts. J Infect Dis, 1988; 157: $770-6$. 
11 Fujiwara T, Izumi S. Synthesis of the neoglycoconjugates of phenolic glycolipid related trisaccharides for the serodiagnosis of leprosy. Agricul Biol Chem, 1987; 51: 2539-47.

12 Chanteau S, Cartel JL, Celerier P, Plichart R, Desforges S, Roux J. PGLI antigen and antibody detection in leprosy patients: evolution under chemotherapy. Int J Lepr, 1989; 57: 735-43.

13 Chanteau S, Plichart R, Boutin JP, Roux JL, Cartel JL. Finger-prick blood collection and computer assisted enzyme-linked immunosorbent assay for large scale serological studies on leprosy. Trans Roy Soc Trop Med Hyg, 83: 414-16.

\title{
L'évaluation de la réaction d'agglutination de particules sur un support gélatineux pour la détection des anticorps anti-PGLI. Comparaison avec la méthode ELISA et son application dans le cadre d'une étude à grande échelle utilisant du sang recueilli sur papier filtre
}

\author{
Suzanne Chanteau, J-L Cartel, J P Boutin et J Roux
}

Résumé Compte tenu des difficultés de la méthode ELISA, une réaction d'agglutination de particules sur un support gélatineux (MLPA) a récemment été mis au point pour détecter les anticorps anti-PGLI. Cette étude avait pour objectif de comparer ces 2 tests. MPLA était moins spécifique que le test ELISA (91\% par rapport à $\left.98 \%, \chi^{2}=66,8, p<0,001\right)$. La sensibilité des deux tests était de $95 \%$ pour le diagnostic des patients pluribacillaires. Dans le cas des patients paucibacillaires, le MLPA était moins sensible que le test ELISA (21\% par rapport à $\left.35 \%, \chi^{2}=6,98, p>0 \cdot 01\right)$. La concordance des résultats positifs et négatifs entre les deux tests était satisfaisante $(85 \%$ à $100 \%)$ sauf pour les individus légèrement séropositifs ( $71 \%)$. La corrélation observée entre la DO (densité optique) obtenue par la méthode ELISA et le titre d'anticorps obtenu par la méthode MLPA était significative sur le plan statistique $(r=0,70, p<0,001)$. Contrairement à ELISA, MLPA ne s'appliquait pas aux prélèvements sanguins absorbés sur papier filtre sans une perte importante de sensibilité. Donc, cette étude a prouvé que le test MLPA ne décelait les anticorps anti-PGLI avec efficacité que dans les cas des patients pluribacillaires.

\section{Evaluación del ensayo de aglutinación de particula en gelatina para le detección de anticuerpos anti-PGLI. Comparición con el método ELISA y su aplicabilidad en estudios de gran escala usando sangre recogida en papel filtro}

\author{
Suzanne Chanteau, J-L Cartel, J P Boutin y J Roux
}

Resumen Debido a las dificultades técnicas del método ELISA, se ha desarrollado recientemente un test de aglutinación de particula en gelatina (MLPA) para la detección de anticuerpos anti-PGLI. El propósito de este estudio fue comparar estos dos tests. Se encontró que el MLPA era menos específico que ELISA $(91 \%$ versus $\left.98 \%, \chi^{2}=66,8, p<0,001\right)$. La sensibilidad de ambos tests fue de $95 \%$ para el diagnóstico de pacientes multibacilares. En el caso de pacientes paucibacilares, se encontró que el MLPA era menos sensibile que ELISA $\left(21 \%\right.$ versus $\left.35 \%, \chi^{2}=6,98, p>0,01\right)$. La concordancia entre los dos tests para un resultado positivo o negativo fue satisfactorio $(85 \%$ a $100 \%)$, excepto para los individuos seropositivos débiles $(71 \%)$. La correlación entre OD obtenida con ELISA y el grado de anticuerpo obtenido con MLPA fue estadisticamente significativo $(r=0,70, p<0,001)$. En forma inversa a ELISA, el MLPA no fue aplicable a muestras de sangre que estaban impregnadas en papel de filtro sin que hubiera una pérdida seria en la sensibilidad. En conclusión, este estudio demostró que el test de MLPA puede detectar anticuerpos anti-PGLI en forma segura solamente en casos multibacilares. 